\title{
CHEMICAL AND THERMOGRAVIMETRY ANALYSIS FOR MUNICIPAL WASTE SLUDGE - CASE SCENARIO ANALYSIS
}

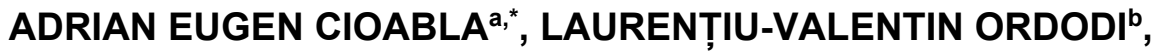 \\ GERLINDE RUSU
}

\begin{abstract}
The need for solutions in the sector of municipal waste management brings different problems which can be properly managed by using modern technologies, new ways to capitalize substrates and materials which in normal conditions are not potentially usable. The present study involves chemical and thermal analysis in order to determine the energetic potential and overall properties of one type of municipal waste sludge collected during summer in Caras-Severin County. For confidential reasons, the origin of the waste sludge will not be mentioned.
\end{abstract}

Keywords: municipal waste sludge, chemical analysis, thermogravimetry

\section{INTRODUCTION}

Waste management is currently one of the biggest problems in both small and large communities. Even if related with the produced waste, a large part can be further processed, separated and further recycled or used in different applications for energy conversion or industrial applications, still, there are large quantities of waste which have currently no solution in terms of large-scale processing and use for further benefits.

The exponential population growth, economic development, and rapid urbanisation are the key contributors to MSW generation [1]. Besides, the high consumption rate and consumer-based lifestyle have been the driving factors towards an increase in MSW generation [2,3]. This increased rate of MSW generation is one of the global issues that contribute to socioeconomic and environmental problems [4]. These waste accumulations have caused severe ecological problems involving air and water pollution.

a Politehnica University of Timisoara, Faculty of Industrial Chemistry and Environmental Engineering, 6 Vasile Parvan blvd., Timisoara, Romania

b Politehnica University of Timisoara, Faculty of Mechanical Engineering, 1 Mihai Viteazu blvd

* Corresponding author: adrian.cioabla@upt.ro 
Besides, uncontrolled increase in waste could trigger a shortage of waste disposal areas [5]. In 2018, an estimated average of 2 billion metric tons/year of waste was generated worldwide, which is predicted to rise to 3.40 billion tonnes by 2050 [6]

The environmental problem of waste, waste-related challenges and sustainable energy supply is being minimised through a range of approaches: $A D$, gasification, fermentation, pyrolysis, and liquefaction [7-9].

Municipal sewage sludge is an unavoidable by-product of wastewater treatment. An increase in the amount of sewage sludge produced has been observed for many years. The amount of generated sewage sludge is only $1-3 \%$ of the volume of flowing sewage [10].

Sewage sludge can be used in agriculture as a valuable source of nitrogen and phosphorus, for production of compost, and for the reclamation of degraded areas $[11,12]$. The choice of the method of sewage sludge management is particularly dictated by its quantity and properties [13]. Moreover, it is subject to legal regulations.

The source of heavy metals in sludge is wastewater, which is mainly generated by plants using galvanic processes, steel pickling, and the recycling of lead batteries.

In this regards, municipal waste waters and waste sludge are of interest in the present material, with impact on a case study in terms of potential uses for the test sludge in co-firing processes.

The present article will underline the base analysis for a proper prepared sludge sample having its origin in the SW part of the country (Banat Region, Caraș - Severin County). The material was analyzed in terms of physical and chemical properties for determining its possible applications. Conclusions were traced in this regard and further recommendations have been made, connected with the obtained results.

\section{RESULTS AND DISCUSSIONS}

After the laboratory determinations were made, the obtained results are presented below.

Table 1. Experimental results (part 1)

\begin{tabular}{|c|c|c|c|c|}
\hline MATERIAL & $\begin{array}{c}\text { Moisture } \\
\text { content } \\
{[\%]}\end{array}$ & $\begin{array}{c}\text { Ash content } \\
\text { (db) } \\
{[\%]}\end{array}$ & $\begin{array}{c}\text { Gross calorific } \\
\text { value (db) } \\
{[\mathbf{J} / \mathbf{g}]}\end{array}$ & $\begin{array}{c}\text { Net calorific } \\
\text { value (db) } \\
{[\mathbf{J} / \mathbf{g}]}\end{array}$ \\
\hline $\begin{array}{c}\text { Waste sludge - Caras- } \\
\text { Severin County }\end{array}$ & 8.51 & 62.2 & 7883 & 7039 \\
\hline
\end{tabular}


From the point of view of the ash content, it can be observed that the minerals inside the material are at a very high level, making it almost impossible to be used in co-incineration processes.

During the laboratory testing the material presented difficulties to be burned in order to determine its calorific value.

Table 2. Experimental results (part 2)

\begin{tabular}{|c|c|c|c|c|}
\hline MATERIAL & $\begin{array}{c}\text { Carbon content } \\
\text { (db) } \\
{[\%]}\end{array}$ & $\begin{array}{c}\text { Hydrogen } \\
\text { content } \\
\text { (db) } \\
{[\%]}\end{array}$ & $\begin{array}{c}\text { Nitrogen } \\
\text { content } \\
\text { (db) } \\
{[\%]}\end{array}$ & $\begin{array}{c}\text { Volatile matter } \\
\text { content (db) } \\
{[\%]}\end{array}$ \\
\hline $\begin{array}{c}\text { Waste sludge - Caras- } \\
\text { Severin County }\end{array}$ & 18.4 & 3.5 & 2.12 & 36.1 \\
\hline
\end{tabular}

The elements presented in the table above are in the normal range for this type of material, indicating relatively low potential for use in co-firing applications.

Table 3. Experimental results (part 3)

\begin{tabular}{|c|c|c|}
\hline MATERIAL & $\begin{array}{c}\text { Sulphur content } \\
\mathbf{( d b )} \\
{[\%]}\end{array}$ & $\begin{array}{c}\text { Chlorine content } \\
\text { (db) } \\
{[\%]}\end{array}$ \\
\hline Waste sludge - Caras-Severin County & 1.5 & 0.12 \\
\hline
\end{tabular}

A very interesting analysis represents the Sulphur and Chlorine contents. Unexpectedly, the Chlorine level is relatively low in this case, but the Sulphur level is high as percentage inside the analyzed sample. This aspect also makes the material not suitable for co-firing applications.

Table 4. Experimental results (part 4)

\begin{tabular}{|c|c|c|c|c|}
\hline MATERIAL & $\begin{array}{c}\text { Shrinking } \\
\text { temperature } \\
{ }^{\circ} \mathbf{C}\end{array}$ & $\begin{array}{c}\text { Deformation } \\
\text { temperature } \\
{ }^{\circ} \mathbf{C}\end{array}$ & $\begin{array}{c}\text { Hemisphere } \\
\text { temperature } \\
{ }^{\circ} \mathbf{C}\end{array}$ & $\begin{array}{c}\text { Flow } \\
\text { temperature } \\
{ }^{\circ} \mathbf{C}\end{array}$ \\
\hline $\begin{array}{c}\text { Waste sludge }- \\
\text { Caras-Severin } \\
\text { County }\end{array}$ & 930 & 1180 & 1230 & 1260 \\
\hline
\end{tabular}

One interesting analysis that could not be made in Romania was the ash melting behaviour. This analysis indicates the way in which the material behaves inside the firing chamber at high temperatures.

The obtained values from measurements indicate a relatively high point of flowing temperature, which is a common factor for this type of material. 
The thermo-gravimetrical analyses (TGA) were performed on TG 209 F1 Libra equipment (Netzsch) under nitrogen atmosphere and under dynamic conditions $10 \mathrm{~K} / \mathrm{min}$ from 20 to $900{ }^{\circ} \mathrm{C}$.

Table 5. TG curves specific points

\begin{tabular}{|c|c|c|c|c|c|}
\hline \multirow{2}{*}{ Sample } & \multicolumn{2}{|c|}{ Inflexion } & \multicolumn{2}{c|}{ Mass loss (\%) } & Residual mass \\
\cline { 2 - 6 } & First step & Second step & $25-150^{\circ} \mathrm{C}$ & $150-600^{\circ} \mathrm{C}$ & \begin{tabular}{c} 
Res \\
\hline $\begin{array}{c}\text { Waste sludge }- \\
\text { Caras-Severin } \\
\text { County }\end{array}$
\end{tabular} \\
\hline
\end{tabular}

The TG curves present two degradation steps:

- the first degradation step occurs between 25 and $150^{\circ} \mathrm{C}$ and has a sharp mass loss being associated to water loss. The mass loss for the first degradation step is under $10 \%$ for the sample.

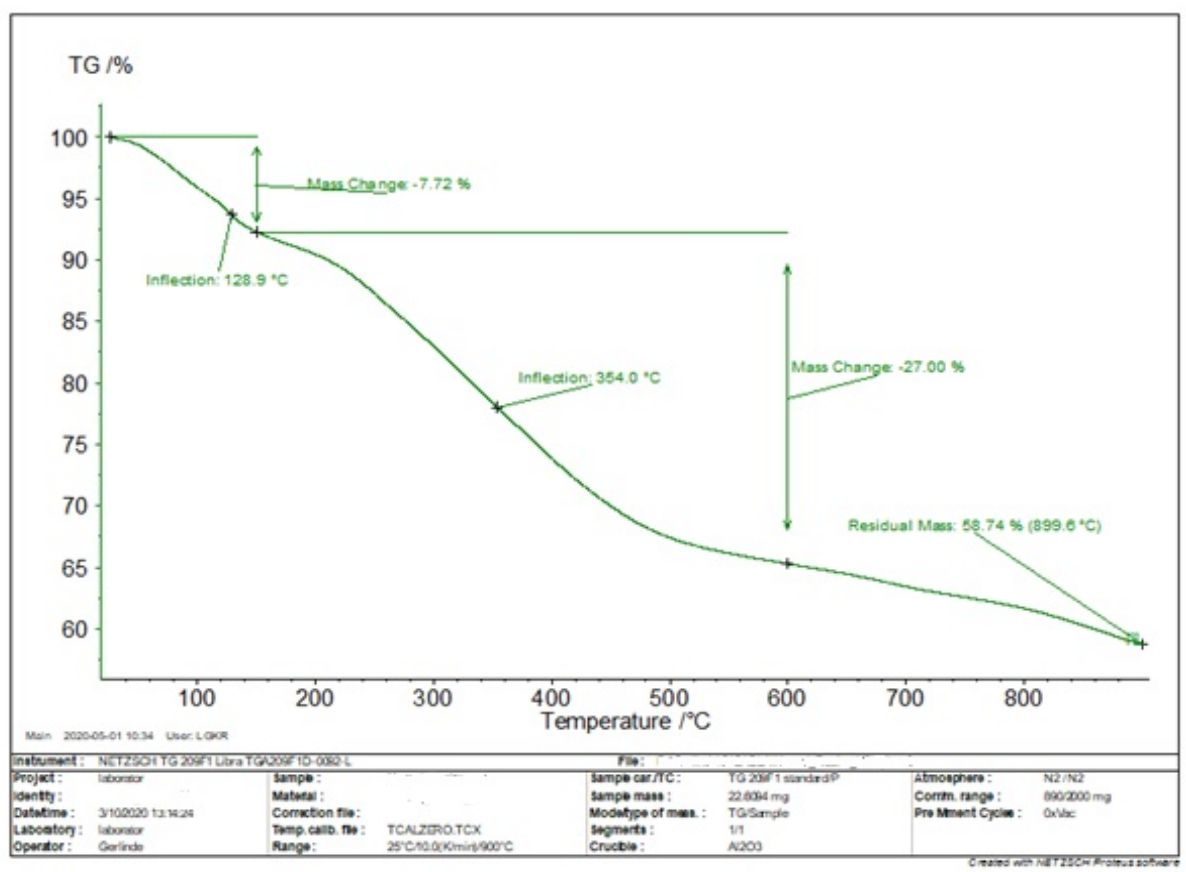

Figure 1. TG curves for analysed sample under nitrogen environment 
- the second from 150 to $600^{\circ} \mathrm{C}$ is associated to thermal decomposition of the organic compounds of the samples. The mass loss is under $30 \%$ for the analyzed material. The high value for the residual mass $(58 \%)$ probably denotes the high inorganic content for the sample.

\section{CONCLUSIONS}

The presented study involved the analysis of a sludge type of material in correlation to determining its properties from a chemical stand point and TG analysis.

Unfortunately, all the presented data (ash content, calorific value, sulphur content) prove that the analysed material is not suitable for co-firing applications. It also has a relatively low calorific level of energy. Usually, summer effluents are filled with high concentrations of organic mass which in turn raise the calorific value, but in this case the presented scenario proves the contrary.

The materials can be used as a base substrate for biogas production, but the estimated rate of success is debatable.

\section{EXPERIMENTAL SECTION}

The next paragraph will underline the overall presentation of the analysed waste sludge.

Table 6. General presentation of material

\begin{tabular}{|c|c|c|c|}
\hline No. & MATERIAL & OBSERVATIONS & $\begin{array}{c}\text { ORIGIN SOURCE AND } \\
\text { DETAILS }\end{array}$ \\
\hline 1. & $\begin{array}{c}\text { Waste sludge - Caras- } \\
\text { Severin County }\end{array}$ & PRE-DRIED MATERIAL & Treatment plant \\
\hline
\end{tabular}

For the laboratory analysis, the next standards were used as methods.

- EN ISO 18134 - Solid biofuels - Determination of moisture content Oven dry method (3);

- EN ISO 18122- Solid biofuels - Determination of ash content;

- EN 14918 - Solid biofuels -Determination of calorific value;

- EN ISO 16948 - Solid biofuels - Determination of total content of carbon, hydrogen and nitrogen 
- EN ISO 16994 - Solid biofuels - Determination of total content of sulfur and chlorine

- EN ISO 18123 - Solid biofuels - Determination of the content of volatile matter.

- CEN/TS 15370 - Determination of ash melting behavior.

\section{ACKNOWLEDGEMENT}

The authors wish to thank the team from the BEA Institut für Bioenergie - Viena, Austria, for all the support given during the analysis made in the laboratory for the studied material.

\section{REFERENCES}

1. Kamaruddin MA; Yusoff MS; Rui LM; Isa AM; Zawawi MH; Alrozi R; Environ Sci Pollut Control Ser, 2017, 24, 26988-27020

2. Kumar A; Samadder S.; Waste Manag, 2017, 69, 407-422

3. Khan D, Kumar A; Samadder SR; Waste Manag, 2016, 49, 15-25

4. Klavenieks K; Dzene KP; Blumberga D; Energy Procedia, 2017,128, 512-519

5. Kumar S; Smith SR; Fowler G; Velis C; Kumar SJ, Arya S; R Soc Open Sci 2017, 4, 160764, 1-14

6. Pham TPT; Kaushik R; Parshetti GK; Mahmood R; Balasubramanian R; Waste Manag, 2015, 38, 399-408

7. Rajendran K; Aslanzadeh S; Johansson F; Taherzadeh MJ; Energy Convers Manag, 2013, 74,183-191

8. Lee XJ; Ong HC; Gan YY; Chen W-H; Mahlia TMI; Energy Convers Manag, 2020, 210, 112707, 1-34

9. $\quad$ Silitonga AS; Mahlia TMI; Kusumo F; Dharma S; Sebayang AH; Sembiring RW; Renew Energy, 2019, 133, 520-527

10. Statistics Poland. Statistical Yearbook of the Regions 2019, Statistics Poland, Warsaw, 2020, Poland

11. Farasat, S; Namli, A; Fresen. Environ. Bull, 2016, 25, 1484-1493

12. Lasaridi KE; Manios T; Stamatiadis S; Chroni C; Kyriacou A; Sustainab., 2018, $10,1-13$

13. Latosi'nska, J; Environ. Prot. Eng., 2017, 43, 105-122 